\title{
ENTREVISTA COM ANDRÉIA GUERINI
}

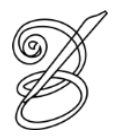 \\ Germana H. Pereira \\ (Doutora - UnB-Brasília/DF/Brasil) \\ germanahp@gmail.com
}

\begin{abstract}
ndréia Guerini é professora associada I do Departamento de Língua e Literatura 1 Estrangeiras da Universidade Federal de Santa Catarina (UFSC) e atua, desde 2011, 1 como professora visitante do Programa de Doutorado em Letteratura, Storia della
\end{abstract} lingua e Filologia Italiana da Università per Stranieri di Siena/Itália. Possui pós-doutorado pela Università degli Studi di Padova (2010) e é doutora em Literatura pela Universidade Federal de Santa Catarina (2001). Guerini é coordenadora da pós-graduação em Estudos da Tradução (PGET) e do grupo de pesquisa do CNPq de Estudos Leopardianos; faz parte da Diretoria da Associação Brasileira de Pesquisadores em Tradução (ABRAPT) - gestão 20112013 - e da Diretoria da Associação Nacional de Pós-Graduação em Letras e Linguística (ANPOLL) - gestão 2012-2014. É editora-chefe da revista Cadernos de Tradução (Qualis A2) desde 2002 e da revista Appunti Leopardiani desde 2011; é autora do livro, publicado pela Edusp em 2007, intitulado Gênero e tradução no Zibaldone de Leopardi.

Você é crítica literária, tradutora e pesquisadora. Como você aproxima esses campos de atuação?

ANDRÉIA GUERINI: Esses três campos estão intimamente interligados e se complementam, mas o perfil de pesquisadora foi o marco inicial para que eu pudesse entrar nas outras duas “categorias" profissionais. A tradução é uma forma particular de leitura, ou, para usar as palavras de Italo Calvino, "é o verdadeiro modo de ler um texto", ou porque para traduzir (refiro-me principalmente aos textos literários) o tradutor deve estar atento às diferentes nuances de forma e de significado/sentido, ou se quisermos usar os termos de Berman, a "letra" do texto, aspectos importantes na análise de qualquer crítico literário. 
Nos seus trabalhos de tradução, como você se inscreve como autora do texto traduzido?

AG: Embora muitas correntes da tradução entendam a tradução como coautoria, particularmente, tenho minhas reservas em me intitular coautor de qualquer texto que eu traduza. Sinto-me mais um intermediário na melancólica tarefa de dar uma "forma" e um "sentido" ao texto que traduzo. Na realidade, compartilho a bela ideia que August Willemsen, tradutor holandês de obras brasileiras, veiculou em um artigo publicado no primeiro número da revista Fragmentos

(ver

<http://www.periodicos.ufsc.br/index.php/fragmentos/article/view/4727/3979>), de que o tradutor escreve através de outro escritor, por isso, ele é o "autor da obra alheia".

Você é tradutora de Leopardi para o português. Quais são as confluências, se é que elas existem, entre seu trabalho e o do Leopardi no campo da tradução?

AG: Embora Leopardi não seja conhecido como teórico da tradução, ele, a partir da sua prática, muito teorizou sobre o assunto, e, em linha de máxima, gosto muito quando ele diz que o ideal de uma tradução é quando o tradutor consegue a "via di mezzo", isto é, quando ele 128 mantém as características do texto de partida sem esquecer as características da língua de chegada, para que o estilo nas duas línguas seja mantido. Naturalmente, essa "via di mezzo" é, como o autor italiano bem sabia, o aspecto mais difícil de se conseguir em qualquer tradução, por isso, quando traduzo, tento seguir esse "conselho", mesmo sabendo que estaremos sempre lidando com perdas e ganhos.

Como tradutora de literatura italiana no Brasil, e sendo uma tradutora e pesquisadora brasileira, como você avalia as traduções e a recepção da literatura italiana no Brasil hoje?

AG: As traduções brasileiras de literatura italiana têm sido, de modo geral, muito boas, pois há uma geração de excelentes tradutores. Cito apenas alguns, Mauricio Santana Dias, Roberta Barni, Nilson Moulin, Marco Lucchesi, Ivo Barroso e tantos outros. O Brasil tem importado regularmente textos de literatura italiana; o problema é que isso não acontece de forma sistemática. Assim, se tomarmos apenas os últimos 30 anos, verificamos que o interesse está principalmente em Dante, com a Divina comédia, seguido pelos autores do século XX, como Italo Calvino e Umberto Eco, dois autores com boa parte de seus livros traduzidos para o português. Dentro desse espaço temporal de aproximadamente seis décadas, não podemos deixar de mencionar o interesse por Machiavelli (ou Maquiavel, como é conhecido no Brasil) com $O$ Príncipe, e Collodi, com Pinóquio. As editoras seguem certa tendência da moda e, 
naturalmente, do mercado, e acabam publicando livros representativos de alguma tendência, como é o caso de Giorgio Agamben, que está tendo praticamente todos os seus livros traduzidos para o português.

Você tem inúmeros artigos publicados no Brasil sobre tradução literária e coordena o primeiro programa de pós-graduação criado no Brasil no campo dos Estudos da Tradução. Como você avalia sua contribuição pessoal para os TS no Brasil?

AG: Não sou a pessoa indicada para responder a essa pergunta.

Como você avalia a visibilidade do trabalho do tradutor hoje no Brasil?

AG: A visibilidade do tradutor, apesar de alguns esforços advindos de algumas pessoas, como é o caso de Denise Bottmann (ver <http://naogostodeplagio.blogspot.com.br>), ou da academia, por meio de cursos de graduação e de pós-graduação, melhorou, mas ainda precisamos reforçar essa visibilidade, incentivando o debate entre as editoras e os cursos de graduação e pós-graduação. É que os paratextos (introduções, prefácios, notas, capa) presentes nas traduções sejam um recurso frequente em qualquer tradução, pois é um dos meios mais eficazes para se dar a tão propagada visibilidade do tradutor, ou ainda, que nós estejamos sugerindo coisas simples, como o de se exigir o nome dos tradutores nas bibliografias de trabalhos acadêmicos e nos sites de editoras e livrarias, ou ainda que reconhecendo e praticando a tabela de pagamento proposta pelo SINTRA (Sindicato Nacional de Tradutores). Enfim, são pequenas ações que ajudariam a reverter essa situação.

Quais as contribuições que os programas de pós-graduação podem trazer para o mercado de tradução literária no Brasil?

AG: Acredito que a médio e longo prazo os programas de pós-graduação poderão ajudar na visibilidade do tradutor, na qualidade dos textos traduzidos e, principalmente, na compreensão da complexidade que é o traduzir.

Qual a relação que os PPG podem instituir com as editoras de literatura estrangeira?

AG: Acredito que podem ser estabelecidos diferentes tipos de parceria, de acordo com interesses específicos, para a melhora da qualidade das obras traduzidas. 
Em sua opinião, qual ou quais os críticos elou teóricos mais importantes para os TS hoje no mundo?

AG: É difícil responder, até porque tanto as teorias prescritivistas como as descritivistas cumpriram/cumprem um determinado papel, e todas servem, em maior ou menor medida, para explicar determinados aspectos, já que não há nenhuma teoria da tradução totalizadora. Muito se teorizou e muito ainda se teoriza. Às vezes, os que não são considerados teóricos da tradução me parecem os mais sofisticados, como Borges, por exemplo. 